\section{Media Publikasi Promosi Kesehatan Indonesia The Indonesian Journal of Health Promotion}

\title{
Determinan Sosial “Quality of Life" Orang dengan HIV dan Aids (Odha)
}

\author{
Sosial Determinant of Quality of life of People with HIV and Aids (Plha)
}

\author{
Acce Basri \\ Politeknik Kesehatan Kementrian Kesehatan Ternate \\ achebasri@gmail.com
}

\begin{abstract}
Abstrak
Kualitas hidup sangat erat kaitannya dengan kehidupan setiap orang terutama orang dengan HIV dan AIDS (ODHA). Penelitian ini bertujuan untuk mengetahui pengaruh stigma, depresi, dukungan sosial, status sosial ekonomi dan kepatuhan minum obat ARV terhadap kualitas hidup orang dengan HIV dan AIDS (ODHA) di Maluku Utara tahun 2016. Penelitian ini merupakan penelitian observasional analitik dengan rancangan "potong lintang". Populasi penelitian adalah seluruh ODHA yang ada dalam wilayah Propinsi Maluku Utara. Sampel penelitian sebanyak 206 responden yang diambil dan ditentukan dengan tehnik purposif. Data dianalisis dengan uji chi-scuare dan regresi logistik melalui bantuan computer program SPSS. Hasil penelitian menunjukkan bahwa nilai stigma ( $\mathrm{p}$ Value $=0,002)$, depresi ( $\mathrm{p}$ Value $=0,001)$, Dukungan sosial ( $\mathrm{p}$ Value $=0,002)$, Kepatuhan terapi ARV ( $\mathrm{p}$ Value $=0,024)$ artinya, keempat factor tersebut berpengaruh terhadap kualitas hidup ODHA. Stigma merupakan variabel yang paling kuat pengaruhnya terhadap kualitas hidup ODHA.
\end{abstract}

Kata Kunci : Stigma; Depresi; Dukungan Sosial; ARV; ODHA

\begin{abstract}
Quality of life is closely related to the life of everyone, especially people with HIV and AIDS (PLWHA). This research aimed to investigate the effect of the stigma, depression, social support, social status, social economy, and compliance to take ARV medicine on the quality of in North Maluku in 2016.The research was an observacional-analytical research using the Crosssectional design. The research population compriced all the ADHA living in the province of north Maluku. The total of the research samples was 206 respondents, who were chosen using the purposive sampling technique. The data were analyzed using computerization with the SPSS application, chi-square test, and logistic regression test.The research results indicated that stig$m a(p$ value $=0.002)$, depression ( $p$ value $=0,001)$, social support $(p$ value $=0.002)$, ARV therapy compliance $(p$ value $=0.24)$ were the variables which affected the quality of life of ODHA. And stigma was the variable which had the strongest effect on the quality of life of $O D H A$.
\end{abstract}

Keywords: stigma; depression; social support; $A R V$; ODHA 


\section{PENDAHULUAN}

Acquired Immune Deficiency Syndrom (AIDS) atau sindrom kehilangan kekebalan tubuh adalah sekumpulan gejala penyakit yang menyerang tubuh manusia sesudah sistem kekebalannya dirusak oleh virus yang disebut $\mathrm{Hu}$ man Immunodeficiency Virus (HIV). HIV adalah virus yang menyebabkan penyakit terutama merusak sistem kekebalan tubuh (1).

Di Indonesia semakin banyak ditemukan kasus HIV AIDS. Hasil laporan Ditjen PPM \& PL Kemenkes RI menyatakan jumlah kumulatif infeksi HIV yang dilaporkan sampai dengan Maret 2014 sebanyak 134.053 kasus. Persentase HIV tertinggi dilaporkan pada kelompok umur 25-49 tahun (72,3\%) diikuti kelompok umur 20-24 tahun (15\%) dan kelompok $\geq 50$ tahun (5,8\%) di mana rasio HIV antara laki-laki dan perempuan adalah 1:1 (2).

Wilayah Maluku Utara jumlah penderita HIV dan AIDS terus meningkat. Sejak tahun 2011 jumlah penderita sebanyak 116 orang, tahun 2012 meningkat menjadi 230 dan tahun 2015 sampai dengan bulan Agustus jumlah HIV dan AIDS sebanyak 588. orang. Dari jumlah infeksi HIV dan AIDS di Maluku Utara tahun 2010-2015, penyumbang terbesar adalah Kota Ternate sebanyak 240 dan kabupaten Halmahera utara 201 (3).

World Health Organization (WHO) mendefenisikan bahwa kualitas hidup adalah persepsi individual terhadap posisinya dalam kehidupan, dalam konteks budaya, system nilai dimana mereka berada dan hubungannya dengan tujuan hidup, harapan, standard dan perhatian. Kualitas hidup mempengaruhi kesehatan fisik, kondisi psikologis, tingkat kemandirian, hubugan sosial dan hubungan pasien dengan lingkungan sekitarnya. faktor yang banyak menyebabkan penurunan kualitas hidup masyrakat adalah penyakit salah satu diantaranya adalah HIV dan AIDS (4)

ODHA adalah sebutan bagi mereka yang secara positif didiagnosa terinfeksi HIV. Belum adanya obat untuk menyembuhkan mereka menjadi suatu ketakutan akan ancaman kematian.Tuapattinaja dalam Munthe (2014), menyatakan bahwa menghadapi kemungkinan meninggal merupakan stressor utama bagi ODHA yang menimbulkan depresi dan reaksi mengisolasi diri dari orang lain. stigma dan diskriminasi di lingkungan masyarakat juga memperberat keadaan mereka.

Penelitian yang dilakukan Yadav (2010), mengenai studi kasus dukungan sosial, harapan dan kualitas hidup orang-orang dengan HIV dan AIDS di Nepal menemukan bahwa orang yang hidup dengan HIV dan AIDS dengan dukungan informasi, dukungan emosional, dukungan sosial dan dukungan jaringan sosial membantu meningkatkan kualitas hidup pasien HIV dan AIDS (5).

Penelitian yang dilakukan oleh Andrinopoulos et al (2011), menyatakan bahwa depresi mempunyai pengaruh terhadap kualitas hidup orang dengan HIV dan AIDS. Dijelaskan bahwa ODHA yang mengalamai depresi melaporkan kualitaas hidup yang rendah (6). Hal ini sejalan dengan penelitian yang dilakukan oleh Doyle et al (2012), menyatakan bahwa kelompok umur yang lebih muda, sangat mudah untuk mengalami depresi dan mempengaruhi kualitas hidup mereka (7).

Dampak sosial dan ekonomi akibat HIV dan AIDS mungkin lebih berat dari penyakit yang lain yang ada didunia. Hal ini bukan hanya jumlah orang yang terinfeksi HIV yang tinggi tetapi juga karena orang yang terinfeksi kebanyakan antara umur 15-49 tahun yang merupakan usia produktif (8).

Meskipun AIDS belum bisa disembuhkan, namun infeksi ini dapat dikendalikan dengan pengobatan Anti Retroviral Viral (ARV). Dari laporan situasi perkembambangan HIV dan AIDS di Indonesia sampai dengan September 2014 tercatat jumlah ODHA yang mendapatkan terapi ARV sebanyak 45.631 orang (3). Kepatuhan pada pengobatan ARV telah diketahui sebagai komponen untuk mencapai keberhasilan suatu program terapi yang optimal. Penelitian tentang kepatuhan tersebut di Negara maju menunjukkan bahwa tingkat kepatuhan yang 
tinggi berkaitan erat dengan perbaikan virologist maupun klinis (9).

Penelitian ini bertujuan untuk mengetahui determinan sosial quality of life (QOL) Orang Dengan HIV dan AIDS (ODHA).

\section{METODE}

Penelitian ini dilaksanakan di Provinsi Maluku utara, Jenis penelitian ini adalah observasional analitik dengan menggunakan desain studi cross sectional. Populasi dalam penelitian ini adalah seluruh ODHA yang ada dalam wilayah Propinsi Maluku Utara. Jumlah sampel sebanyak 206 orang. Pengambilan sampel menggunakan metode purposive sampling. Data primer diperoleh langsung dari responden dengan melakukan wawancara dan observasi dimana responden diberikan kesempatan untuk mengisi daftar pertanyaan sesuai Kuesioner yang telah disiapkan. Data sekunder diperoleh dari instansi terkait yaitu dari dinas kesehatan provinsi Maluku Utara. Analisis data dilakukan dengan program SPSS dan uji statistik dengan menggunakan uji univariat dengan frekuensi, bivariat $p$ Value dan multivariate dengan Regresi logistic berganda.

\section{HASIL}

Tabel 1 menunjukkan bahwa dari 206 responden yang menjadi sampel penelitian jumlah terbanyak adalah laki-laki sebesar 128 orang (62.1\%) . Proporsi kelompok umur dalam penelitian ini yang tertinggi adalah 30-39 tahun sebanyak 92 responden (44.7\%) sedangkan terendah pada kelompok umur $\geq 50$ tahun 10 responden (4.9\%). Sedangkan responden yang terlibat dalam penelitian ini tertinggi pada jenjang pendidikan SMA yaitu 120 orang (58.3\%) dan terendah pada jenjang pendidikan SD sebanyak 31 orang $(8,7 \%)$.

Hasil analisis pada tabel 2 menunjukkan bahwa pada variabel tentang stigma proporsi tertinggi adalah mereka yang memiliki stigma dengan kategori rendah yaitu sebesar 153 (71,3\%). Untuk variabel depresi menunjukkan bahwa proporsi tertinggi adalah kategori tidak depresi sebanyak 192 (93,2\%). Untuk dukungan social yang diterima ODHA, sebagian besar menyatakan bahwa mendapatkan dukungan sosial dengan kategori tinggi sebanyak 109 (52,9\%). Sedangkan status social ekonomi responden pada penelitian ini, tertinggi pada kategori social ekonomi rendah sebesar 108 (52,4\%). Kepatuhan mengikuti terapi ARV terdapat 144 orang (69,9\%) yang patuh dan 62 (30.1) tidak patuh.

Terlihat pada tabel 3 hasil analisis antara stigma dengan kualitas hidup ODHA menunjukkan bahwa responden yang mengalami stigma rendah, lebih banyak memiliki kualitas hidup tinggi, yaitu sebanyak 104 orang (68\%).Hasil analisis dengan chi square diperoleh nilai $\mathrm{p}=0,002(\mathrm{p}<0,05)$ yang berarti ada hubungan antara stigma dengan kualitas hidup ODHA. Untuk variabel depresi menunjukkan bahwa responden yang tidak mengalami depresi, lebih banyak memiliki kualitas hidup baik, yaitu sebanyak 124 orang (64.6\%). Hasil analisis dengan chi square diperoleh nilai $\mathrm{p}=0,001(\mathrm{p}<0,05)$ yang berarti ada hubungan antara depresi dengan kualitas hidup ODHA, variabel dukungan sosial menunjukkan bahwa responden yang mendapatkan dukungan sosial tinggi, lebih banyak mengalami kualitas hidup yang tinggi, yaitu sebanyak 78 orang (73.5\%). Hasil analisis dengan chi square diperoleh nilai $\mathrm{p}=0,003(\mathrm{p}<0,05)$ yang berarti ada hubungan antara dukungan sosial dengan kualitas hidup ODHA. Hasil analisis sosial ekonomi menunjukkan bahwa responden dengan status sosial ekonomi tinggi, lebih banyak mengalami kualitas hidup baik sebanyak 62 orang (63.3\%). Hasil analisis dengan chi square diperoleh nilai $\mathrm{p}=0,650$ ( $\mathrm{p}>0,05)$ yang berarti tidak ada hubungan antara dukungan sosial dengan kualitas hidup ODHA. Sedangkan hasil analisis bivariat antara kepatuhan terapi ARV dengan kualitas hidup ODHA menunjukkan bahwa responden yang patuh menjalani terapi ARV, lebih banyak memiliki kualitas hidup baik, yaitu sebanyak 96 orang $(66,6 \%)$. Hasil analisis dengan $c h i$ 
square diperoleh nilai $\mathrm{p}=0,029(\mathrm{p}<0,05)$ yang berarti ada hubungan antara kepatuhan terapi ARV dengan kualitas hidup ODHA.

Tabel 4 menunjukkan bahwa dari 3 variabel yang diikutkan pada analisis multivariate, yaitu stigma, depresi dan dukungan sosial . Hasil analisis menunjukkan bahwa seluruh variabel bermakna terhadap kualitas hidup ODHA Dengan Probabilitas 87,3\%, dimana stigma merupakan variabel yang paling berpengaruh.

\section{PEMBAHASAN}

Penelitian ini menunjukkan bahwa responden yang mengalami stigma rendah, lebih banyak memiliki kualitas hidup tinggi, responden yang tidak mengalami depresi lebih banyak mengalami kualitas hidup baik, responden yang mendapatkan dukungan social yang tinggi lebih banyak mengalami kualitas hidup yang tinggi dan responden yang patuh menjalani terapi ARV, lebih banyak memiliki kualitas hidup baik serta status responden dengan status social ekonomi tinggi lebih banyak mengalami kualitas hidup baik pada ODHA di Maluku Utara tahun 2016.

Stigma adalah tindakan memberikan label sosial yang bertujuan untuk memisahkan atau mndeskreditkan seseorang atau sekelompok orang dengan cap atau pandangan buruk. Penelitian yang dilakukan oleh Herrmann et al (2013), menunjukkan bahwa kesulitan untuk hidup bagi ODHA terutama dalam hal hibungan intim stigma yang dirasakan dan kesehatan kronis yang buruk akan berdampak terhadap kualitas hidup (10). Hal yang sama dengan penelitian yang dilakukan oleh Mutabazi-Mwesigire et al (2014), menyatakan bahwa responden masih banyak menderita stigma, ketakutan, pengungkapan dan kemiskinan yang berdampak negative terhadap kualitas hidup mereka (11).

ODHA yang menganggap menerima stigma yang masuk dalam kategori rendah sabesar 67,1\%. Melihat kontribusi stigma terhadap kualitas hidup memang masih sangat kecil karena beberapa responden masih menutup diri (menyembunyikan statusnya) baik terhadap keluarga pasangan maupun lingkungan sekitar. Hal ini akan berdampak pada banyak hal terutama dalam hal pencegahan. Selain itu status yang ditutupi dimasyarakat akan menyebabkan ODHA akan kurang bersosialisasi dengan lingkungannya. Kurangnya sosialisasi baik dalam keluarga maupun tetangga akan menyebabkan ODHA tidak mengetahui kondisi jelas yang terjadi apakah ODHA di stigma atau tidak.

Depresi adalah kondisi medis yang mempengaruhi pikiran, perasaan dan kemampuan untuk berperan dalam kehidupan sehari-hari. Meskipun terapi yang tersedia dapat mengurangi gejala HIV lebih dari $80 \%$ dari penderita yang dirawat, sebagian penderita dengan depresi kurang memperoleh bantuan dari apa yang mereka batuhkan untuk mengurangi depresinya.

Zhao et al (2013), menyatakan bahwa depresi secara signifikan berkorelasi dengan kualitas hidup disemua domain. Hasil analisis regresi berganda penelitian lain juga menunjukkan bahwa suasana hati (depresi) dapat mempengaruhi kualitas hidup ODHA (12). Hasil penelitian ini menunjukkan bahwa responden yang mengalami depresi sebesar 6.8\%. ODHA yang mengalami depresi adalah ODHA yang baru mengetahui statusnya. Hasil penelitian ini sama dengan yang dilakukan oleh Cimermancic et al (2012), juga menyatakan bahwa ODHA yang mengalami depresi berat hanya meningkatkan kualitas hidup yang buruk (13).

Secara psikis seseorang yang terinfeksi HIV dan AIDS akan merasa cemas, marah, takut dan perasaan bersalah, hal ini dibuktikan dari item kuesioner depresi yang mendapatkan sebanyak 62,3\% pasien HIV dan AIDS terhadap hal-hal yang dilakukannya. Apabila kondisi tersebut berlangsung dalam jangka waktu lama, maka dapat menimbulkan depresi yang mengarah pada kehampaaan hidup serta mengembangkan hidup tidak bermakna

Kepatuhan pengobatan anti retro viral pada ODHA merupakan hal yang esensial selama pengobatan HIV dan AIDS. Terapi anti retro viral dapat memperpanjang hidup ODHA, meskipun tidak dapat menyembuhkan infeksi 
HIV. Terapi anti retro viral dapat menekan jumlah virus di tubuh ODHA dengan pemakaian secara terusmenerus. Kelalaian meminum obat bisa menyebabkan resistensi.

Faktor internal utama yang mendukung kepatuhan adalah adanya motivasi dari dalam diri penderita untuk tetap bertahan hidup, tingkat kesadaran tinggi akan fungsi dan manfaat ARV serta keimanan terhadap agama/ keyakinannya. Motivasi dari dalam diri penderita untuk sembuh atau bertahan hidup merupakan faktor pendukung kepatuhan yang paling sering dinyatakan oleh responden. Teknologi yang berkembang secara terus menerus turut serta memberikan kontribusi dengan ditemukanya obat bagi penderita HIV AIDS, yaitu obat yang bisa melawan virus ini, namun tidak bisa mematikannya. Hal inilah yang menjadi faktor utama penderita HIV dan AIDS di Maluku Utara tidak mengalami perubahan keadaan ekonomi, sebelum dan sesudah terkena virus HIV AIDS. Penderita HIV dan AIDS masih bisa bekerja secara normal dengan catatan harus selalu mengkonsumsi obat tersebut setiap hari.

Hasil penelitian ini berbanding lurus dengan penelitian Zhang et al (2012), yang menyatakan bahwa rumah tangga ODHA yang bekerja pasca diagnosis memiliki tingkat pendapatan yang lebih tinggi dibandingkan dengan rumah tangga ODHA yang berhenti bekerja pasca diagnosis (12). Pendapatan per kapita rumah tangga berhubungan dengan status perkawinan, karena status kawin dapat memberikan penghasilan tambahan secara signifikan

Penelitian ini menunjukkan bahwa intervensi kebijakan tertentu, seperti membantu rumah tangga mengembangkan portofolio lebih tangguh dari kegiatan pertanian, dapat membantu melindungi rumah tangga yang rentan terhadap beberapa guncangan akibat dari HIV.

\section{KESIMPULAN}

Penelitian ini menyimpulkan bahwa ada pengaruh antara stigma, depresi, dukungan social dan terapi ARV terhadap kualitas hidup ODHA, variabel yang paling kuat pengaruhnya adalah stigma. Disaraankan. Pengurangan stigma dan diskriminasi pada ODHA haruslah melibatkan organisasi keagamaan yang ada didaerah tersebut. Organisasi keagamaan mempunyai kekuatan strategis dalam mempersuasi masyarakat mengingat organisasi keagamaan merupakan rujukan dari masyarakat dalam berfikir, bersikap dan bertindak. ODHA dapat, menambah wawasan tentang HIV dan AIDS dengan cara mengikuti seminar, mengikuti penyuluhan,membaca dan lain-lain,sehingga nantinya dapat menjadikan persepsi ODHA terhadap HIV/AIDS menjadi positif, menjalani hidup lebih optimis, mampu mengembangkan diri dan mampu meningkatkan kualitas hidu. Pihak-pihak terkait yang perhatian terhadap kesejahteraan ODHA hendaknya lebih ditingkatkan lagi pemberian dukungan sosial kepada ODHA. Untuk meningkatkan kepatuhan ODHA dalam minum ARV diperlukan peran keluarga, teman dan manager kasus

\section{DAFTAR PUSTAKA}

1. Joerban Z. Membidik AIDS, Ikhtiar memahami HIV dan ODHA. Galang Press; 2008. 11 p.

2. Kementerian Kesehatan RI. Situasi penyakit HIV AIDS di Indonesia. Pus Data dan Inf Kementeri Kesehat RI. 2016;

3. Kemenkes RI. Kementerian kesehatan republik indonesia. Hari Aids Sedunia 2014. 2014.

4. Organization WH, others. Diagnostic criteria for HIV-related clinical events: adults and adolescents. 2013;

5. Yadav S. Perceived social support, hope, and quality of life of persons living with HIV/AIDS: a case study from Nepal. Qual Life Res. 2010;19(2):157-66.

6. Andrinopoulos K, Clum G, Murphy DA, Harper G, Perez L, Xu J, et al. Health related quality of life and psychosocial correlates among HIV-infected adolescent and young adult women in the US. 
AIDS Educ Prev. 2011;23(4):367-81.

7. Doyle T, Smith C, Vitiello P, Cambiano V, Johnson M, Owen A, et al. Plasma HIV-1 RNA detection below 50 copies $/ \mathrm{ml}$ and risk of virologic rebound in patients receiving highly active antiretroviral therapy. Clin Infect Dis. 2012;54(5):724-32.

8. Amiruddin R. Epidemiologi Perencanaan Kesehatan. Makassar: Megasena Press; 2015.

9. Galistiani GF, Mulyaningsih L. Kepatuhan Pengobatan Antiretroviral Pada Pasien HIV/AIDS Di RSUD Prof. Dr. Margono Soekarjo Purwokerto. Media Farm. 2013;10(2).

10. Herrmann C, Gern L. Survival of Ixodes ricinus (Acari: Ixodidae) nymphs under cold conditions is negatively influenced by frequent temperature variations. Ticks Tick Borne Dis. 2013;4(5):445-51.

11. Mutabazi-Mwesigire D, Seeley J, Martin F, Katamba A. Perceptions of quality of life among Ugandan patients living with HIV: a qualitative study. BMC Public Health. 2014;14(1):343.

12. Zhao G, Perilla JR, Yufenyuy EL, Meng X, Chen B, Ning J, et al. Mature HIV-1 capsid structure by cryo-electron microscopy and all-atom molecular dynamics. Nature. 2013;497(7451):643.

13. Cimermancic P, Gulbahce N, Johnson JR, Mcgovern KE, Clarke SC, Shales M, et al. Global landscape of HIV - human protein complexes. Nature. 2012;481(7381):5-10. 
LAMPIRAN

Tabel 1

Distribusi Responden Berdasarkan Karakteristik di Maluku Utara Tahun 2016

\section{Karakteristik}

Frekuensi

Persen $(\%)$

\section{Kelompok Umur}

18 - 29 Tahun

30 - 39 Tahun

40 - 49 Tahun

$\geq 50$ Tahun

Jenis Kelamin

Laki-laki

Perempuan

\section{Tinggkat Pendidikan}

Tamat SD

$18 \quad 8.7$

Tamat SMP

Tamat SMA

Tamat Perguruan Tinggi

Tabel 2

Distribusi Responden Berdasarkan Variabel Penelitian di Maluku Utara Tahun 2016

\begin{tabular}{lcc}
\hline \multicolumn{1}{c}{ Variabel Penelitian } & Frekuensi & Persen (\%) \\
\hline Stigma & 53 & 25,7 \\
a. Stigma Tinggi & 153 & 74,3 \\
b. Stigma Rendah & & \\
Depresi & 14 & 6,8 \\
Depresi & 192 & 93,2 \\
Tidak Depresi & & \\
Dukungan Sosial & 97 & 47,1 \\
Dukungan Rendah & 109 & 52,9 \\
Dukungan Tinggi & & \\
Social Ekonomi & 108 & 52.4 \\
Rendah & 98 & 47.6 \\
Tinggi & & 30,1 \\
Terapi ARV & 62 & 69.9 \\
Patuh & 144 & 100 \\
Tidak patuh & 206 & \\
Jumlah & & \\
\hline
\end{tabular}


Tabel 3

Hubungan Antara Variabel penelitian Dengan Kualitas Hidup ODHA di Maluku Utara Tahun 2016

\begin{tabular}{|c|c|c|c|c|c|c|c|}
\hline \multirow{3}{*}{ Variabel Penelitian } & \multicolumn{4}{|c|}{ Kualitas Hidup } & \multirow{2}{*}{\multicolumn{2}{|c|}{ Jumlah }} & \multirow{3}{*}{$\begin{array}{l}\text { Nilai } \\
p \text { Value }\end{array}$} \\
\hline & \multicolumn{2}{|c|}{ Rendah } & \multicolumn{2}{|c|}{ Tinggi } & & & \\
\hline & $\mathrm{n}$ & $\%$ & $\mathrm{n}$ & $\%$ & $\mathrm{n}$ & $\%$ & \\
\hline \multicolumn{8}{|l|}{ Stigma } \\
\hline Tinggi & 30 & 56.6 & 23 & 43,4 & 53 & 100 & \multirow[t]{2}{*}{$\mathrm{P}=0,002$} \\
\hline Rendah & 49 & 32 & 104 & 68 & 153 & 100 & \\
\hline \multicolumn{8}{|l|}{ Depresi } \\
\hline Depresi & 11 & 78,6 & 3 & 21,4 & 14 & 100 & \multirow{2}{*}{$\mathrm{P}=0,001$} \\
\hline Tidak depresi & 68 & 35,4 & 124 & 64,6 & 192 & 100 & \\
\hline \multicolumn{8}{|l|}{ Dukungan Sosial } \\
\hline Rendah & 48 & 52,7 & 49 & 47,3 & 97 & 100 & \multirow[t]{2}{*}{$\mathrm{P}=0,002$} \\
\hline Tinggi & 31 & 26,5 & 78 & 73,5 & 109 & 100 & \\
\hline \multicolumn{8}{|l|}{ Sosial Ekonomi } \\
\hline Tinggi & 43 & 39,8 & 65 & 60,2 & 108 & 100 & \multirow{3}{*}{$\mathrm{P}=0,650$} \\
\hline Rendah & 36 & 36,7 & 62 & 63,3 & 96 & 100 & \\
\hline Terapi ARV & & & & & & & \\
\hline
\end{tabular}

Tabel 4

Hasil Analisis Multivariat Kualitas Hidup ODHA di Maluku Utara Tahun 2016

\begin{tabular}{llll}
\hline \multicolumn{1}{c}{ Variabel } & \multicolumn{1}{c}{ B } & \multicolumn{1}{c}{ Wald } & Sig \\
Stigma & 0,882 & 6,561 & 0,010 \\
Depresi & 1,481 & 4,530 & 0,033 \\
Dukungan Sosial & 0,782 & 6,393 & 0,011 \\
Constant & $-1,221$ & 25,759 & 0,000 \\
\hline
\end{tabular}

